Preprints of the

Max Planck Institute for

Research on Collective Goods

Bonn 2008/3

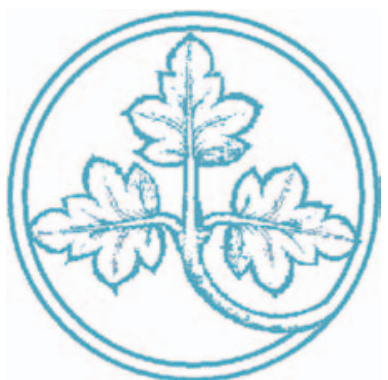

Pharmaceutical research in Wilhelmine Germany: The case of E. Merck

Carsten Burhop

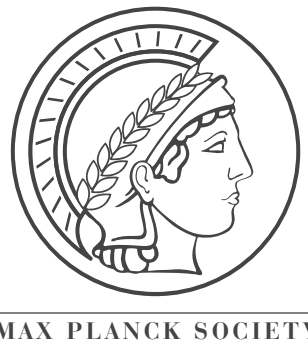




\section{Pharmaceutical research in Wilhelmine Germany: The case of E. Merck}

Carsten Burhop

February 2008 


\title{
Pharmaceutical research in Wilhelmine Germany: The case of E. Merck
}

\author{
Carsten Burhop ${ }^{\dagger}$
}

\begin{abstract}
In this paper, we describe the emergence and evolution of pharmaceutical research at the German company E. Merck during the late $19^{\text {th }}$ and early $20^{\text {th }}$ century. Revolutionary changes in the scientific knowledge base, especially the rise of bacteriological research, and the market entry of dyestuff producers into pharmaceuticals made the re-organisation of pharmaceutical research during the 1890s a necessary corporate strategy. Consequently, Merck restructured its in-house research between 1895 and 1898. Moreover, the firm deepened its co-operation with universities and other outside inventors. Jointly and severally, the firm depended on outside inventors for the generation of new products, whereas in-house scientists improved the productive efficiency. Moreover, we show that a significant number of new products were launched between the late 1890s and 1905. During the following years, however, resource constraints restricted Merck's innovative capacity.
\end{abstract}

JEL-Classification: N 83, O 32

Keywords: Business history; pharmaceutical research; case study

I would like to thank Katja Glock of the corporate archive of E. Merck, Darmstadt, who discovered and supplied many useful files. Comments made by Brian Cooper and Thorsten Lübbers substantially improved the paper. All remaining errors and shortcomings are the sole responsibility of the author. Financial support of the Deutsche Forschungsgemeinschaft is gratefully acknowledged.

$\dagger \quad$ Max Planck Institute for Research on Collective Goods, Kurt-Schumacher-Straße 10, 53113 Bonn, Germany, Email: burhop@coll.mpg.de 


\section{Introduction}

Germany's rise to one of the leading industrial economies during the late $19^{\text {th }}$ and early $20^{\text {th }}$ century was, among many other reasons, ascribed to its ability to innovate. In particular, Germany's success during the 'second' industrial revolution was connected to the inventions made in the fields of chemistry, pharmacy, and electrical engineering. In turn, the inventive activity was fostered by the high quality of Germany's system of higher education, the substantial governmental support for science, and - last but not least - the emergence of industrial research laboratories (Landes, 1999: 290-291; Cameron / Neal, 2003: 242-243).

More specifically, the invention of the company-sponsored research organisation was identified as the undoubtedly greatest single contribution of the German dyestuff industry (Beer, 1959: 73). This path-breaking organisational revolution transformed the firms from fellow-runners to market leaders in synthetic dye production. At least since Beer's observation, the research laboratories of the dyestuff industry itself had been the object of scientific research. The focus of these studies had been the development at Bayer (e.g., Beer, 1959; Meyer-Thurow, 1982; Murmann, 2006) whereas the two other major dyestuff producers, BASF and Hoechst, were much less intensively investigated (Homburg, 1992; Reinhardt 1997). ${ }^{1}$

Yet, the evidence of a science-based second industrial revolution is much less clear for other industries. König $(1995,1996)$ showed that the causality between industrial development and scientific research was opposite in electrical engineering, compared to the experience of the dyestuff industry. Electrical engineering was an industry-driven science, not a science-driven industry. In addition, Erker (1990) pointed out that professionally managed centralized research laboratories emerged during the 1920s, and not during the pre-World War I period. Before World War I, research was decentralized at the major German electrical engineering firms Siemens and AEG. Moreover, centralized research laboratories appeared at about the same time in the U.S., Germany, and other European states.

Turning to the pharmaceutical industry, findings by Wimmer (1994) show that professionally managed in-house research and development (R\&D) was constricted to Bayer, whereas Hoechst procured new products from universities and only improved the production process in-house. ${ }^{2}$ Furthermore, the traditional pharmaceutical company Schering failed to develop a R\&D strategy during the pre-World War I period (Wimmer, 1994; Kobrak, 2002). Jointly and severally, it seemed that the professionally managed centralized corporate R\&D laboratory was constricted to dyestuff production. Moreover, all but one dyestuff firm - Bayer - failed to transfer the R\&D organisation to the new field of pharmaceuticals. ${ }^{3}$

A detailed case study from the pharmaceutical industry is potentially important for this debate in several respects. First of all, most studies regarding the emergence of corporate R\&D focus on

Reinhardt (1998) contains a short English summary of the main findings of his monograph. Wimmer (1998) contains a short English summary of the main findings of his monograph.

Nevertheless, Liebenau $(1984,1985)$ showed that German firms were market leaders in pharmaceutical research compared to their American and British competitors. 
the dyestuff industry. This industry clearly deserves a substantial amount of attention, since industrial $R \& D$ laboratories were invented in this industry. On the other hand, dyestuffs were relatively unimportant in terms of output. In 1913, they accounted for only 3.5 percent of the value of the worldwide chemical production, whereas pharmaceuticals accounted for 17.5 percent (Ungewitter, 1931: 6). Second, the pharmaceutical knowledge base experienced a major shift during the 1870s and 1880s. More specifically, the sources of bacteriological infections were discovered and treatments for them were developed. Moreover, it turned out that dyestuffderivatives could be used as antipyretics and analgesics. Consequently, traditional pharmaceutical firms, whose knowledge based mainly on alkaloid chemistry, were faced with a new knowledge base and with the market entry of the major dyestuff producers into the drug market. ${ }^{4}$ Faced with this shift in general conditions, the major dyestuff and pharmaceutical firms adapted their behaviour. $^{5}$

This paper offers a detailed case study about the emergence, organisation, and development of R\&D at E. Merck, the oldest pharmaceutical company in the World. ${ }^{6}$ So far, only the expansion of the research laboratories of the German dyestuff producers Hoechst, Bayer, and BASF towards pharmaceutical research as well as $R \& D$ at the traditional pharmaceutical firm Schering had been evaluated (Wimmer, 1994; Reinhardt, 1995; Kobrak, 2002). These case studies showed a substantial heterogeneity in the organisation of R\&D: Bayer developed strong in-house research capacities, Hoechst mostly relied on long-term research co-operations with university researchers, Schering depended upon the creativity of an individual in-house researcher, and BASF left the pharmaceutical market quite soon.

Merck is an important case study for at least three reasons. First, Merck is a much older firm than Hoechst, Bayer, BASF, and Schering, which were all established during the 1860s, whereas Merck dates back to the late $17^{\text {th }}$ century and was established as a general partnership in 1827 . Consequently, its learning base and organisational structure were built up during a different state of scientific knowledge. Second, Merck was a family-owned and managed firm whereas the large competitors were publicly quoted joint-stock companies, often with outside managers. Third, Merck was a major player in pharmaceutical research. Taking the number of innovative pharmaceutical products on sale in 1911/ 12 as a measure, Merck was number four on the German market (Wimmer, 1994: 228).

By and large, our case study shows a success story. We present evidence that Merck was not captured by its traditional knowledge base or its family-based management. Jointly and severally, Merck’s R\&D strategy was similar to Hoechst’s strategy. Merck mostly relied on external

4 Moreover, the role of small pharmacies and the distribution of drugs changed significantly after the introduction of industrial production (Wimmer, 1991).

5 This shift in the knowledge base is comparable to the shift induced by the bio-tech revolution of the 1970s. Galambos / Sturchio (1998) evaluate the bio-tech revolution from the perspective of business history. Dominguez-Lacasa (2006) evaluates the consequences of established knowledge bases at German pharmaceutical companies for the adaptation to the new technology since the 1970s.

$6 \quad$ Huhle-Kreutzer (1989: 121-150) described the innovative activity of Merck from the 1830s until the 1950s from a medical-historical perspective. 
researchers for the development of new products. Nevertheless, the firm had substantial in-house research capacities, which were radically re-organized in 1898 with the establishment of its central research laboratory. The main activity of this laboratory was the screening of dozens of inventions offered by outside inventors and the improvement of production processes. However, Merck's success strongly depended on a small number of blockbuster drugs. In this respect, the firm was similar to its main competitors. Moreover, Merck failed to devote substantial resources to in-house R\&D. Consequently, when the supply of product innovations from outside innovators flattened during the last years preceding the Great War, Merck's innovativeness declined substantially.

The remaining parts of the paper are organized as follows. In Section II, an aggregate picture of R\&D at Merck between the 1890s and World War I is depicted. Section III describes Merck's external sources of innovation, e.g., cooperation with universities and the buying of production innovations on the market for technology. Section IV presents the in-house R\&D capacities of the firm. The final Section V concludes the paper.

\section{The development of E. Merck}

Merck's history can be traced back to 1688, when Friedrich August Merck bought the EngelApotheke ('Angel pharmacy') in Darmstadt, a small city south of Frankfurt. The move to industrial production was initiated in 1827 by Emanuel Merck, who founded, together with his sons Carl, Georg, and Wilhelm, the business partnership E. Merck. From the 1880s onwards, the third generation of the Merck family controlled the business. All family members were well trained to manage the company: Carl's oldest and youngest sons, Johann Heinrich Emanuel Merck and Carl Merck, received both a management education and were responsible for the commercial affairs of the company until 1897/98, when this activity was taken over by the chemists Louis Merck, the third brother, until his death in 1913. Georg's sons, Emanuel August Merck and Willy Merck, were responsible for the sales department (1883-1923) and the production department (1886-1932), respectively. Both had received a PhD in chemistry and pharmacy before entering the firm. Willy's sons, Carl Emanuel Merck, a chemist, and Georg Merck - who had a degree in management - managed the social affairs department (1888-1909) and the U.S. subsidiary (1891-1926), respectively (Bernschneider-Reiff, 2002: 64-65). ${ }^{7}$

Beyond changes in the top management of the firm, the invention of bacteriological drugs and the use of dyestuffs as pharmaceuticals were two major changes of the scientific basis of pharmaceutical research, which both occurred during the 1880s. This made a fundamental restructuring of R\&D indispensable. Moreover, changes in the scientific basis caused the market entry of

$7 \quad$ American readers should note that Merck \& Co., Whitehouse Station, U.S., was founded in 1891 as the U.S. subsidiary of the German firm E. Merck. After the confiscation during World War I, Merck \& Co. became an independent company. Today, the firms are not linked together, but share the same name. Merck \& Co. has the right to use the name in the U.S., but outside the U.S. it is known as Merck Sharpe \& Dohme (MSD). Merck KGaA, in turn, has the right to use the name outside the U.S. and operates in the U.S. as EMD (for E. Merck, Darmstadt). The early history of MSD is analyzed by Galabmos / Sewell (1995). 
the large chemical firms Hoechst, Bayer, and BASF into the market for pharmaceuticals. Consequently, the competitive and technological pressure on Merck increased substantially during the 1880s and 1890s.

The path-breaking bacteriological and immunological research conducted by Louis Pasteur and Robert Koch since the 1870s resulted into the discovery of the tubercle bacillus in 1882 and the cholera bacillus one year later. ${ }^{8}$ In a very short period thereafter, almost all infectious diseases had been identified and pharmaceutical research related to these findings started soon. In a first step, vaccines against bacteriological infections were invented, followed by the development of sero-therapy. This latter type of medical treatment was brought forward by Emil von Behring and Paul Ehrlich. ${ }^{9}$ In 1894, they developed the first drug in this line of research, an antidiphtheric serum. In 1910, Paul Ehrlich invented the first antibiotic, Salvarasan, which was the first drug to cure syphilis and a blockbuster for Hoechst, one of Merck’s main competitors.

The usefulness of dyestuffs as pharmaceuticals was discovered during the 1880s. The first major drug in this regard, the antipyretic Kairin, was originally developed in search of a new dyestuff, but launched as a drug in 1883 by Hoechst (Wimmer, 1994: 150-151). The other German dyestuff firms followed soon with similar drugs: BASF introduced Thallin in 1885, Kalle \& Co. launched Antifebrin in 1886, and Bayer rolled Phenacetin out in 1888 (Reinhardt, 1995: 253-254). ${ }^{10}$

Merck was not the first mover using the new pharmaceutical knowledge base. For instance, the three Nobel-Prize winning researchers Koch, von Behring, and Ehrlich signed research contracts with the dyestuff and pharmaceutical company Hoechst in 1892 and 1894, respectively. Moreover, Hoechst, as well as Bayer, deepened their in-house pharmaceutical research capacities. In turn, this increased the pressure on traditional pharmaceutical companies to collaborate with university researchers and to establish own research units. Consequently, the Berlin-based company Schering established a bacteriological department in 1893 and hired a scientist for general pharmaceutical and chemical research at about the same time. Merck followed soon and opened its bacteriological unit in 1895 (Bernschneider-Reiff, 2002: 55-57). In addition, Merck deepened its research co-operations with university researchers by establishing relationships with I. Stilling (in 1890), Rudolf Kobert (in 1892), Martin Freund (in 1895), Hugo Winternitz (in 1897), Josef von Mering (in 1898), Richard Wolffenstein (in 1900), and Richard Willstätter ${ }^{11}$ (in 1900). Furthermore, the internal organization of R\&D at Merck was re-organized in 1898 with the establishment of the central scientific laboratory. ${ }^{12}$

8 Robert Koch received the Nobel Prize for medicine in 1905, Louis Pasteur died in 1895, before the endowment of the Nobel Foundation.

9 Emil von Behring was the first winner of the Nobel Prize for Medicine. Paul Ehrlich received the Nobel Prize for Medicine in 1908.

10 These changes in the medical knowledge base made it more and more difficult for individual pharmacists to produce all known drugs by themselves. Thus, the production of pure basic chemicals as well as of ready-touse prescription and over-the-counter (OTC) drug shifted to industrial firms. Merck, for example, distributed such ready-to-use prescription and OTC drugs as 'specialities' (Patent- und Specialpräparate) to pharmacies, doctors, and consumers (Bernschneider-Reif, 2002: 53-54).

11 In 1915, Richard Willstätter received the Nobel Prize for Chemistry.

12 MRO, F3 / 2c. 
The major shifts in the scientific and organisational environment of the 1880s and 1890s are also numerically visible, in input as well as in output figures. Global input factors for a firm are the number of employees and the value of capital in use. More specifically for R\&D are the number of employees and the money spent on these activities. The total number of Merck's employees increased continuously from 714 in 1895 to 1,135 in 1901, and finally to 2,082 in $1914 .^{13}$ The number of scientists employed in the central research laboratory was, on the other hand, roughly constant at about eight researchers between 1898 and World War I. Yet, the total number of researchers employed by the firm was larger, since some researchers were located in other departments of the company, for example in the bacteriological laboratory, the scientific information department, the control laboratory, and in several production units. ${ }^{14}$

A more comprehensive picture of resources devoted to R\&D can be gained by locking at the amount of money spent. The in-house research budget was, compared to modern standards, moderate. ${ }^{15}$ The average research budget spent during the three business years 1902/ 03 to 1904/ 05 was 93,197 Mark, about 7 percent of profits or 0.8 percent of turnover. ${ }^{16}$ In addition, Merck spend on average 16,923 Mark on its R\&D cooperation with university researchers. ${ }^{17}$ More specifically, this money was used to buy licences from professors and to equip their laboratories with staff and material. Moreover, various outside inventors - who were mainly university professors - received on average about 80,000 Mark per year as remuneration for their inventions used by Merck. ${ }^{18}$ Therefore, Merck spent on average about 190,000 Mark on R\&D at the turn of the $20^{\text {th }}$ century. ${ }^{19}$

A widely-used, albeit incomplete, measure of innovative output is the number of patents granted. ${ }^{20}$ For Germany, this indicator is available from 1877 onwards, since the first unified German patent law was enacted during this year. Yet, the grant of pharmaceutical and chemical patents became much easier after the 1891 patent law reform act and the number of patents granted to these industries increased substantially thereafter. ${ }^{21}$ Compared to the U.S. and U.K.

13 MRO F3/2a, MRO F3/5a, and MRO F3/18a. Thus, Merck was much smaller than the big chemical companies BASF, Bayer, and Hoechst, but larger than Schering (1,227 employees in 1913), Chemische Fabrik von der Heyden (1,509 employees), and J.D. Riedel (1,001 employees), see Ungewitter (1931).

14 In 1912-14, the number of scientists in the central research laboratories of BASF, Bayer, and Hoechst was 29, 15, and 28, respectively (Reinhardt, 1997: 286, 365-366; Marsch, 2000: 66).

15 In 2006, Merck invested about 12 percent of its turnover into R\&D.

16 During 1902-04, the average annual research budget of the pharmaceutical firm C.F. Boehringer \& Söhne (Mannheim) was 110,233 Mark and that of Knoll \& Co. (Ludwigshafen) was 36,514 Mark. In terms of assets and profitability, both firms were much smaller than Merck. Boehringer was about half the size of Merck, whereas Knoll was only about one-sixth of Merck's size. MRO H5/43.

17 MRO H5/43.

18 Own calculations from Merck’s internal annual reports, MRO F3/7a, MRO F3/8a, and MRO F3/9a.

19 Detailed figures about the research budget are not available for later years. However, the number of researchers in the central laboratory was more or less constant until World War I. Therefore, the expenditures for inhouse research can be expected to remain constant. Expenditures for external research, on the other hand, increased substantially. In 1912, for example, Merck spent about 300,000 Mark to compensate outside inventors.

20 Grilliches (1990) reviews the usefulness of patents as an indicator for innovations. More specific for the German historical context are Grupp et al. (2002) and Metz / Watteler (2002).

21 See Seckelmann (2005) for a detailed account of the history of Germany's patent law. On aggregate, the number of patents granted in 1893-95 was 14 percent higher than the number of patents granted in 1890-92. 
patent systems, four features of the German patent law were outstanding. First, a patent was granted to the person registering the patent at the patent office and not to the true inventor. Consequently, inventions made by employed inventors were granted to the firms employing them. ${ }^{22}$ Moreover, long-term research contracts between firms and university researchers often allocated the patent to the firm. ${ }^{23}$ Second, a detailed technical examination of the invention was made by the patent office. In addition, patent infringements were mostly settled in the period between the publication of a patent application and the grant of the patent. Therefore, patents granted represented secure property rights. ${ }^{24}$ Third, it was compulsory to put the patent into use within three years after it was granted. Consequently, individual inventors or university professors had a strong incentive to sell or licence their patents to firms. Fourth, patenting of pharmaceutical final products was forbidden by patent law; only the production process could be patented. Moreover, even patenting of processes was quite difficult until the 1891 patent law reform. Thus, imitation of final products of competitors using slightly modified processes was common practice. ${ }^{25}$ In turn, safeguarding final products via patenting of a set of different production processes was necessary.

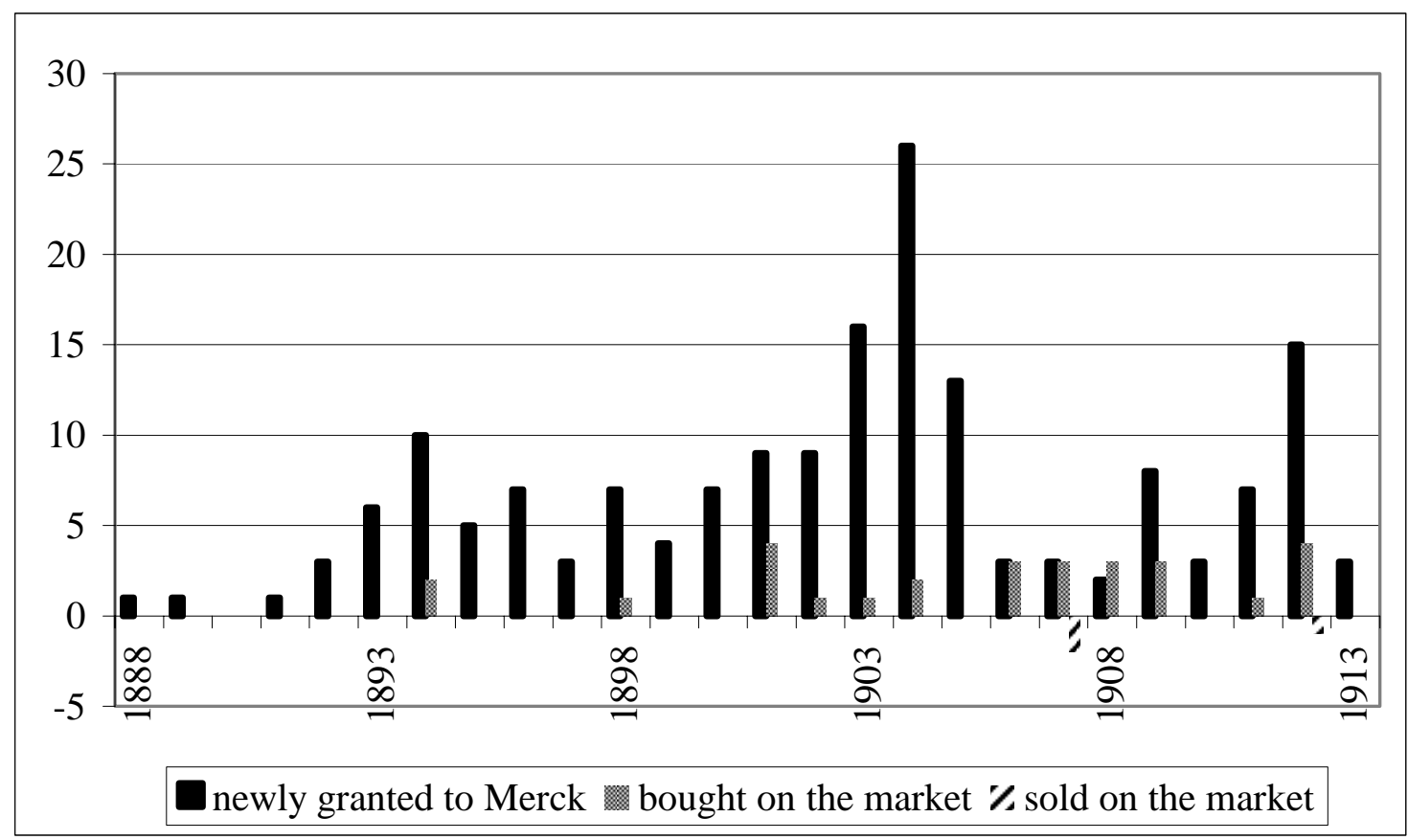

Figure 1

Annual patenting activity by Merck

Source: Kaiserliches Patentamt, Verzeichnis der erteilten und in Kraft befindlichen Patente, various years.

Patents for the chemical and pharmaceutical industries (technology classes 12 and 22) increased, on the other hand, by about 87 percent.

22 More than 60 percent of all patents were granted to firms.

23 See Section III for the case of Merck.

24 Less than 0.4 percent of the patents granted were repealed after the grant.

25 Lee (2003) showed that coexistence of innovation and imitation within one firm was common in the U.S. pharmaceutical industry until the 1940s, whereas thereafter firms were either innovators or imitators. 
Merck received its first patent on 6 October 1885 (patent-no. 35,724) for a method to manufacture peptone using nucleon proteins (Löw, 1952: 47). ${ }^{26}$ Until the reform of the patent law in 1891, Merck’s patenting activity was nearly non-existent (see Figure 1). From 1892 onwards, on the other hand, eight patents were on average granted to Merck annually. In addition, Merck bought 28 patents from other inventors and sold three patents on the market for intellectual property rights. As could be expected, nearly all of Merck’s patents (151 out of 174) were granted in the technology class "Chemical methods and instruments". ${ }^{27}$

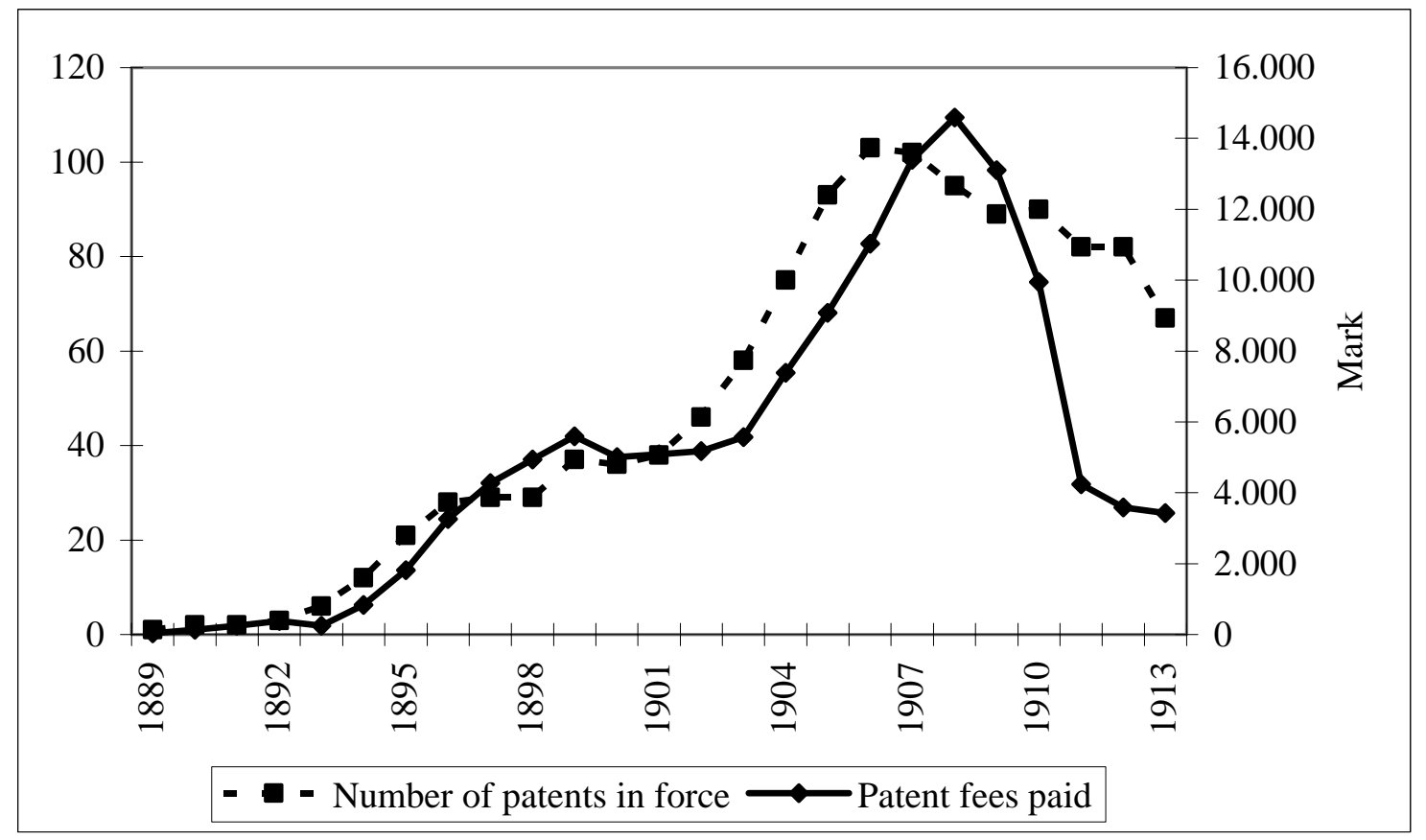

Figure 2

Merck's patent stock and its cost

Source: Kaiserliches Patentamt, Verzeichnis der erteilten und in Kraft befindlichen Patente, various years.

The annual flow of new patents granted to Merck or acquired by Merck resulted into a growing stock of patents held by the company. In turn, the costs of keeping the patents active increased substantially during the early $20^{\text {th }}$ century (see Figure 2 ). ${ }^{28}$ Merck's patent stock surpassed ten in 1894 and 100 in 1905. The fees paid surpassed 5,000 Mark in 1899 and 10,000 Mark in 1906. The patent stock of the company peaked in 1907/ 08 with 117 patents in force (1907) and 14,590 Mark fees paid (1908) respectively. Thereafter, the patent stock and the fees paid declined substantially to 74 patents in force and 3,430 Mark fees paid in 1913. The patent data thus show a

26 Peptones are used as a culture medium in bacteriological research.

27 The Imperial Patent Office allocated the patent classification according to the industry of use, not according to the industry of origin.

28 Keeping a patent in force was expensive in the German Empire. The owner of a patent had to pay an annual fee, which increased from 30 Mark for the first year to 50 Mark for the second year, 100 Mark for the third year, 150 Mark for the fourth year, and so on. The fee for the 15th and final year was 700 Mark. Thus, the cumulated fee for 15 years of protection was 5,280 Mark, about 6.5 times the annual per capita income in 1913. 
marked increase in innovative activity at Merck during the first years of the $20^{\text {th }}$ century, followed by a crisis of innovation during the years preceding the Great War.

R\&D resources were converted into patentable innovations, and these innovations should have been used in final products sold by Merck. Therefore, resources devoted to R\&D and patenting activity should be visible in output figures for R\&D intensive products. In general, Merck doubled its turnover from 5.7 million Mark during the business year 1894/ 95 to 11.5 million Mark in 1902/ 03 and then again to 23 million Mark in 1912. ${ }^{29}$ The turnover of Merck's specialities (i.e., prescription and OTC drugs) increased, on the other hand, by factor four between the turn of the century and World War I. ${ }^{30}$ Furthermore, prescription and OTC drugs were very profitable. In 1902/ 03, Merck’s total profit was 1.36 million Mark, about 11.8 percent of the annual turnover. $^{31}$ In 1912, total profits were roughly 3.9 million Mark, about 17 percent of the turnover. In 1902/ 03, about 13.1 percent of the total profits were generated by the specialities. Ten years later, in 1912, about 28.5 percent of the profits were made with these R\&D intensive products. $^{32}$ This illustrates the rising importance of R\&D intensive products for Merck.

As today, pharmaceutical companies generated most of the profits with a small number of blockbuster products. Table 1 shows Merck’s blockbuster products. The table is derived from the product-specific accounts, which Merck kept for its most important products. The productspecific accounts include information about turnover, marketing expenditure, profits, and remuneration of outside inventors. In 1897/ 98, eleven products were separately accounted for, in 1912, 53 products were already covered by such detailed accounts. ${ }^{33}$

29 In 1913, Bayer generated a turnover of about 22 million Mark with pharmaceuticals (Wimmer, 1994: 143). Hoechst's turnover with pharmaceuticals was about 4.8 million Mark in 1909 and 6.4 million Mark in 1910 (Wimmer, 1994: 185). Schering generated a total turnover of about 16.8 million Mark in 1913 (Ungewitter, 1931: 55-62). Consequently, Merck was much smaller than Bayer, but of Hoechst's size in the field of pharmaceuticals. Schering, on the other hand, was smaller than Merck.

30 MRO, F3/1b, MRO, F3/7c, MRO F3/16d. Until 1906, Merck's business year ran from 1 July to 30 June. It was changed to the calendar year from 1907 onwards.

31 MRO H5/43.

32 MRO F3/16d. Schering's turnover (net profit) was 8,947 Million Mark (465 million Mark) in 1895 and 16,840 Million Mark (1,416 million Mark) in 1913 (Kobrak, 2002: 360-361). Therefore, Merck had a faster growth of turnover and a higher profitability than Schering.

33 MRO F3/1b and MRO F3/16a. Moreover, separate accounts are available for the 27 products covered by a pharmaceutical cartel agreement. Burkert (1990) described the history of this cartel agreement. 


\begin{tabular}{|c|c|c|c|c|}
\hline & \multicolumn{2}{|c|}{$\begin{array}{l}\text { From product launch } \\
\text { until } 1913\end{array}$} & \multicolumn{2}{|c|}{$\begin{array}{l}\text { From product launch } \\
\text { until } 1918\end{array}$} \\
\hline & in Mark & Rank & in Mark & Rank \\
\hline Stypticin & $1,190,520.70$ & 1 & $1,603,771.47$ & 1 \\
\hline Dionin & $967,335.69$ & 2 & $1,290,547.51$ & 4 \\
\hline Jodipin & $646,946.08$ & 3 & $763,577.11$ & 5 \\
\hline Perhydrol & $571,993.02$ & 4 & $1,325,977.57$ & 3 \\
\hline Tannoform & $388,272.03$ & 5 & $733,313.91$ & 6 \\
\hline Veronal & $356,348.31$ & 6 & $1,490,926.51$ & 2 \\
\hline Haemol & $245,372.95$ & 7 & $261,828.56$ & 10 \\
\hline Magnesium-Perhydrol & $218,218.18$ & 8 & $491,174.53$ & 8 \\
\hline Pyoktanin & $142,383.81$ & 9 & $401,653.26$ & 9 \\
\hline Fibrolysin & $114,844.23$ & 10 & $195,535.43$ & 11 \\
\hline Total & $4,842,235.00$ & & $8,558,305.86$ & \\
\hline
\end{tabular}

MRO, S 6-21 and S 6-22.

Merck's most important product was the haemostasis drug Stypticin, which generated a profit of nearly 1.2 million Mark between its launch in 1897 and the end of 1913. Dionin, a morphine derivative antitussive drug, generated profits of nearly one million Mark between its rollout in 1898 and 1913. Jodipin and Haemol were both bacteriological drugs used in fighting streptococcus, tubercle, and syphilis. Perhydrol and Magnesium perhydrol were disinfectants applied in dentistry and - in a lower concentration - as a mouthwash. Veronal, which was jointly developed and sold with Bayer, was the first barbiturate. Pyoktanin, which based on dyestuffs, was used to treat mycosis of the eye. Fibrolysin and Tannoform, finally, were used to sanitise wounds, the latter also in treatment of intestinal diseases. ${ }^{34}$

Similar product-specific accounts were also kept at Bayer and Hoechst (Wimmer, 1994: 120122, 185-187). In 1897, for example, Bayer generated a turnover of 4.66 million Mark and a profit of 1.36 million Mark with its most important pharmaceuticals (Wimmer, 1994: 120). This compares to a turnover of only 0.43 million Mark and profits of about 67,000 Mark at Merck during the business year 1897/ 98. Consequently, Merck's drug business was much smaller and less profitable during the late 1890s than Bayer's. In addition, few blockbuster products were responsible for the major part of turnover and profits at all companies. In 1909, for example, Hoechst generated about half of its pharmaceutical turnover with its two top-selling drugs, Antipyrin and Pyramidon (Wimmer, 1994: 185-186). In a similar fashion, Merck generated 40 percent of its pharmaceutical turnover with its two blockbuster drugs Veronal and Dionin in $1909 .^{35}$

34 It is important to note that Merck made substantial profits producing more traditional products. For example, Merck's cocaine production generated a turnover of more than 1.5 million Mark and a profit of more than 400,000 Mark in 1912.

35 In 1913, Schering generated drug sales of 2.7 Million Mark, about 15.9 percent of the total sales of the company. The two most important drugs, Atophan and Urotropin, accounted for nearly three-quarters of Schering’s pharmaceutical sales (Kobrak, 2002: 364). 
The above mentioned data regarding the money spend for $R \& D$ already suggested that a substantial part of the R\&D expenditures was used to compensate outside inventors. Actually, Merck's top ten drugs of the pre-World War I era were all invented by outside inventors (see Table 2). In this respect, Merck was very similar to Hoechst: 21 out of 24 of Hoechst's high-value pharmaceuticals developed between 1883 and 1909 were invented by outsiders (Wimmer, 1994: 185).

TABLE 2: SOURCES OF MERCK'S TOP PRODUCTS

\begin{tabular}{|c|c|c|c|c|}
\hline & Inventor & $\begin{array}{l}\text { Type of or- } \\
\text { ganisation }\end{array}$ & $\begin{array}{l}\text { Year of } \\
\text { invention }\end{array}$ & $\begin{array}{l}\text { Share in profits } \\
\text { for inventor (on } \\
\text { profits until } \\
1918 \text { ) }\end{array}$ \\
\hline Stypticin & Martin Freund & University & 1897 & $31.2 \%$ \\
\hline Dionin & Joseph von Mering & University & 1898 & $27.0 \%$ \\
\hline Jodipin & Hugo Winternitz & University & 1902 & $20.3 \%$ \\
\hline Perhydrol & $\begin{array}{l}\text { Richard Wolffen- } \\
\text { stein }\end{array}$ & University & 1900 & $8.6 \%$ \\
\hline Tannoform & Joseph von Mering & University & 1895 & $5.1 \%$ \\
\hline Veronal & $\begin{array}{l}\text { Emil Fischer / Jo- } \\
\text { seph von Mering }\end{array}$ & University & 1903 & $36.8 \%$ \\
\hline Haemol & R. Kobert & University & 1892 & $50.0 \%$ \\
\hline Magnesium-Perhydrol & $\begin{array}{l}\text { Richard Wolffen- } \\
\text { stein }\end{array}$ & University & 1903 & $8.1 \%$ \\
\hline Pyoktanin & I. Stilling & University & 1890 & $25.2 \%$ \\
\hline Fibrolysin & Dr. F. Mendel & free inventor & 1905 & $22.6 \%$ \\
\hline
\end{tabular}

MRO, F 3 (diverse files); MRO R 15 / 11; MRO R 15 / 12.

Merck's top product Stypticin was invented by Martin Freund, a professor of medicine in Frankfurt. Moreover, Freund invented the less successful, but still profitable, drugs MethylNarcotamid and Hydrastinin. The most important outside inventor for Merck was most likely Joseph von Mering, professor of medicine at the University of Halle. Mering, born 1849 in Cologne, studied medicine in Bonn, Strasbourg, and Greifswald. He earned his PhD in Strasbourg in 1874 and worked in clinics in Strasbourg and Halle. Finally, he was appointed to a full professorship and directorship of the University clinic in Halle in 1900. He was the inventor of two of Merck's top-selling drugs (Dionin and Tannoform) and the co-inventor of Veronal. Moreover, he invented two of the less profitable drugs sold by Merck. ${ }^{36}$

36 The drug Peronial earned a profit of 26,014 Mark until 1913. Hydrogen peroxide earned a profit of 21,447 Mark. Other university professors co-operating with Merck were the Nobel Prize winner Emil Fischer, inventor of Proponal and co-inventor of Veronal; Hugo Winternitz, inventor of Jodipin, Bromipin, Chineonal, and Luminal; and Richard Wolffenstein, inventor of Perhydrol, Magnesium-Perhydrol, and Zinc-Perhydrol. 


\section{Research collaboration and the market for technology}

Until today, the collaboration of industrial firms and universities is an important component of pharmaceutical research (Chandler, 2005). During the two decades preceding World War I, the emergence of such co-operation was fostered by Germany's patent law, which prescribed the application of a patent within three years after it was granted. Otherwise, the patent was repealed and the knowledge was available for free. Consequently, university professors and other outside inventors, who did not possess the necessary means to produce drugs on a large scale, were forced to sell or licence their patent. University professors as well as firms realized this problem in advance and often closed long-term research contracts, which allocated the right of use of a patent to the firm and a substantial remuneration to the inventor.

For example, Merck’s most successful drug, Stypticin, was developed by Martin Freund, a professor of medicine in Frankfurt, during the 1890s. This drug was based on water soluble crystals being vasoconstrictive and was used as haemostasis drug. The business relationship between Merck and Freund began in February 1891, when they signed a long-term research contract. The stipulations agreed upon in this contract are typical for other contracts closed by Merck. The contract ran for at least five years, but was prolonged automatically thereafter if both parties did not terminate the agreement with a period of notice of 15 months. Merck paid a fixed amount of 2,000 Mark annually to Freund, who had to spend this money to hire a research assistant and to cover the running expenses of his research laboratory. In turn, all product or process innovations discovered had to be presented to Merck before publication in a scientific journal. All innovations became the joint property of Merck and Freund and the firm decided on the commercial exploitation of the invention. If the innovation seemed to become a commercial success, Merck had to produce and distribute it on an industrial scale. Freund, on the other hand, had to support the diffusion of knowledge about the innovation in the scientific community, to fill the patent in Merck's name, and to defend the patent against infringements of third parties. In addition, all profits were shared between Merck and Freund. For each product, the exact profit share of the two parties depended on the degree of patent protection. In general, Freund's share varied between 15 and 50 percent of the accounting profit. ${ }^{37}$ In the case of the blockbuster Stypticin, for example, Freund's profit share was 30 percent of the net profit, indicating that the patent was not water-proof. $^{38}$

One result of the product-specific profit sharing was that Merck kept product specific accounts for up to 80 products during the pre-World War I period. These accounts contain information about revenues, production costs, and marketing costs. More specifically, the production costs included the running expenses for chemicals, heating material, wages, etc., as well as information about depreciation (capital costs) for the capital stock used for the production of a single drug. The accounting method was standardized, and most of Merck's outside inventors had the

37 A very similar contract was closed in March 1901 with Richard Willstätter. Willstätter received a fixed compensation of 6,000 Mark annually, the relevant material free of charge, and a profit share of 25 percent. MRO R15/12. 
right to inspect the accounts. By and large, the accounts were undisputed during the pre-1913 era. Only one conflict regarding the accounts is documented for the pre-World War I period. From 1903 onwards, Merck sold the blockbuster barbiturate Veronal, which was invented by Joseph von Mering and Emil Fischer. Several years after the successful launch of the drug, Emil Fischer pointed to the fact that the depreciation on the capital stock used for the production of Veronal was too high and therefore his profit share too low. During a meeting, Merck informed Fischer that Merck's usual depreciation rate on buildings was five percent per annum. Fischer, however, pointed out that a depreciation rate of two percent would be sufficient. Without any discussion, Merck agreed to this request, adapted the accounts, and used the new depreciation rate for this product from 1907 onwards. ${ }^{39}$

Controversies regarding the assessment base for the compensation of outside inventors emerged more often. Generally, outside inventors could receive a fixed amount and / or a variable amount related to profits, revenues, or output. By and large, Merck - as well as other chemical and pharmaceutical companies - favoured a variable compensation, since then the risk was shared between the inventor and the firm, whereas a fixed compensation shifted the risk towards Merck. Most outside inventors agreed without debate to a variable compensation. Yet, whether the variable compensation was based on profits, revenues, or output was disputed. For example, Martin Freund, the inventor of Stypticin, and Merck negotiated about the modus of Freund's compensation for several months during 1906-07..$^{40}$ The starting point was Merck's offer to switch from a profit-based compensation of 30 percent of the accounting profits to an output based compensation of 80 Mark per kg from May 1906. ${ }^{41}$ Yet, Freund figured out that his average compensation since the launch of the drug equalled about 15 percent of the turnover, or about 85 Mark per kg. Merck justified its lower offer by continuously rising wages, increasing input costs, and growing costs for administration and marketing. In particular, Merck pointed to the tremendously rising costs for noscapine, the most important input factor for the production of Stypticin. ${ }^{42}$ It soon turned out that Freund and Merck could not agree on a fixed compensation per kg. Thus, the profit-sharing agreement remained in force. In September 1907, the discussion came up again when Martin Freund visited Merck's factory. At this opportunity, Freund pointed to the fact that the profit-turnover ratio of Stypticin had been declined recently. Freund offered two possible solutions: Merck could increase the price for Stypticin or could switch Freund's compensation to a turnover- or output-based measure. Again, Merck pointed to the rising costs for noscapine and to a profit-sharing agreement closed with Knoll, the producer of the competing drug Stypta, which complicated the switch from a profit-based compensation to any other form of compensa-

39 Letter from Merck to Fischer, 7 February 1908, MRO H5/15. In this letter, Merck informed Fischer that the acquisition costs for the buildings and other fixed assets used for the production of Veronal were 97,500 Mark and 142,280 Mark, respectively.

40 This is documented in various letters of Freund, Merck, and the competing pharmaceutical firm Knoll. MRO F1/47.

41 Merck and Freund agreed upon an output-based compensation for another product, hydrastinin hydrochloricum, in 1902. Contract between Merck and Freund, 1 July 1902, MRO R5/23. Letter from Merck to Freund, 20 December 1906. MRO F1/47. 
tion since then the contract closed with Knoll had to be adapted. ${ }^{43}$ Consequently, the profitsharing agreement between Freund and Merck remained in force. ${ }^{44}$

One key responsibility of outside inventors was the protection of the patent against infringements by competitors. As a matter of course, a successful product like Stypticin encouraged competing firms to develop similar products. The success of the drug is clearly visible in output and profit figures: the amount sold rose from $11.2 \mathrm{~kg}$ in 1897 to $187.6 \mathrm{~kg}$ in 1902; productions costs declined from 253 Mark to 142 Mark per kg during the same period; marketing costs decreased from 175 Mark to 53 Mark per kg. The price per kg, on the other hand, remained on a high level, decreasing only from 703 Mark in 1897 to 562 Mark in 1902. Consequently, profits per kg increased substantially from 205 Mark in 1897 to 311 Mark in $1902 .{ }^{45}$

Already in 1896, Merck had expected that the Stypticin patent was vulnerable and fixed Freund's share in profits at 30 percent, well below the maximum of 50 percent agreed upon in the FreundMerck research contract for a water-proof patent, but also much higher than the minimum share in profit of 15 percent. In January 1903, Merck’s patent was bypassed by the German pharmaceutical company Knoll \& Co., which received a patent for a close substitute, Stypta. Martin Freund filed an objection against Knoll's patent at the Imperial Patent Office and a long-lasting legal dispute was fought between Freund and Merck, on one side, and Knoll and Dr. Vieth - the inventor of Knoll's product Stypta - on the other.

After three years of conflict, Knoll approached Merck to close a market-sharing agreement for Stypticin and Stypta. ${ }^{46}$ Knoll proposed a profit-sharing agreement allocating at least two-thirds of the joint profits of both firms to Merck. If the profits generated by Merck were higher than two-thirds of the joint profits, Merck would not transfer any profits to Knoll. This proposal indicates that Knoll's patent most likely infringed Merck’s patent. Moreover, Knoll asked Merck to close the agreement very soon since the Patent Office expected an elaboration of Knoll's patent within two weeks. Soon, Merck regarded Knoll's proposal with favour and agreed to withdraw its patent litigation after signing a profit-sharing agreement. The two firms negotiated the details of the market sharing agreement during the following two months and finally signed a contract, which was valid from 1 July $1906 .^{47}$

Beyond the long-term research co-operation with university professors, Merck bought many inventions from university professors as well as from free inventors. ${ }^{48}$ This can be exemplified using the contracts closed with Dr. F. Mendel and Professor Hugo Winternitz, two inventors of

43 Letter from Merck to Knoll, 12 September 1907. MRO F1/47.

44 Finally, Merck and Freund switched from profit-sharing to another form of variable compensation in 1912. Yet, the details of these negotiations are not documented in the files.

$45 \quad$ MRO F1/47.

46 Letter Knoll to Merck, 30 April 1906, MRO F1/47.

47 Knoll's entry on the product market had consequences for prices, costs, and profits. Between January 1903 and June 1906, the average price per kg was 573 Mark, production costs were 165 Mark, marketing costs were 71 Mark, and profits were 280 Mark. Compared to the period before Knoll's market entry, the market price for the final product remained about constant. On the other hand, the production and marketing costs increased substantially. Consequently, profits per kg decreased by about ten percent compared to 1902. 
Merck's top products highlighted in Tables 1 and 2. Dr. Mendel was a medical practitioner in Essen and inventor of Fibrolysin, a drug used to sanitise wounds. According to the contract closed on 5 January 1905, Merck applied for a patent and trademark protection for the drug and produced, advertised, and distributed it on an industrial scale. Mendel, in turn, received 15 percent of the accounting profits made during the validity of the patent. ${ }^{49}$

The second example concerns Hugo Winternitz, a professor for medicine, who was inventor of Bromipin (patented in 1897) and Jodipin (patented in 1902), two bacteriological drugs. On 29 May 1900, Merck agreed to produce and distribute the two drugs. In case of Bromipin, Winternitz licensed these rights to Merck, whereas in case of Jodipin, Merck bought (in 1904) the entire patent. In turn, Winternitz received a compensation of 7.50 Mark per kg of pure Bromipin and 12-15 Mark per kg of pure Jodipin. These payments were, however, not fixed, but could be adapted to changing input or output prices. Moreover, the compensation was only payable as long as the patent was valid. ${ }^{50}$ Consequently, Merck stopped payments to Winternitz for Bromipin in 1912 and for Jodipin in 1917. Moreover, the compensation for Jodipin was halved in 1912 to account for changing market conditions. Nevertheless, the output-based compensation scheme was indeed very lucrative for Winternitz. For Bromipin, he received 29,610 Mark until 1912, about half of the total profits generated by this drug between 1897 and 1912. The Jodipin deal was less lucrative in relative terms for Winternitz, but more lucrative in absolute terms. Between 1902 and 1911 Winternitz received 140,730 Mark, about one-quarter of the profits generated by the product. Between 1912 and 1917, when the patent expired, he received another 14,341 Mark, which equalled less than eight percent of the drug's profits. Jointly and severally, the Bromipin-Jodipin deal was very profitable for both parties: until 1918, Winternitz earned nearly 185,000 Mark from his inventions and Merck got a profit share of about 650,000 Mark. ${ }^{51}$

Merck's activity on the market for innovations went far beyond these acquisitions of blockbuster drugs. The company bought, among many others, inventions for the production of dental cement $^{52}$, the cost-efficient production of hydroquinone ${ }^{53}$, the manufacture of the pneumococcus serum Jequiritol ${ }^{54}$, the manufacture of anthrax sera ${ }^{55}$, and the production of the cinnamic acid product Zebromal ${ }^{56}$. A count of the product and process innovations highlighted in the annual reports of Merck's scientific laboratory shows that 44 percent of all product innovations - not all innovations discussed in the reports were commercially or technically successful - had their origin in university laboratories, 28 percent were prepared by free inventors, and only 28 percent were made in-house. Altogether, close relationships with university researchers were the most

\footnotetext{
49 MRO R 15/12. The product was very profitable until 1916 and generated smaller profits thereafter. Between 1905 and 1918, Mendel received 44,024 Mark for his innovation from Merck. MRO S6/21 and MRO S6/22.

50 Contract between Merck and Winternitz, 29 May 1900; MRO R 15/12. Letter Merck to Winternitz, 31 October 1911; MRO R 15/12.

51 In 1912, Winternitz sold Chineonal to Merck. This drug was less successful than Bromipin and Jodipin and earned a cumulated loss of more than 25,000 Mark until 1918. MRO S 6/21 and MRO S 6/22.

52 Contract between Merck and Carl Böttinger, 12 October 1898; MRO R 1/42.

53 Contract between Merck and A. Lindemann, 23 April 1903; MRO R 1/42.

54 Contract between Merck and P. Römer, 6 May 1905; MRO R 1/42.

55 Contract between Merck and Georg Sobernheim, 10 December 1901; MRO R 1/42.

56 Contract between Merck and A. Ellinger, 10 April 1912; MRO R 15/11.
} 
important source of product innovations for Merck, whereas the existing research capacity inside the firm was not sufficient to generate a continuous flow of new and commercially successful products.

\section{In-house R\&D}

Merck's in-house research capacities were rather unimportant for the generation of new products. Nevertheless, several important tasks were fulfilled by Merck's researchers: they tested the product innovations offered by outside inventors, they scaled the production of new drugs and chemicals up from laboratory conditions to industrial production units, they tested the quality of inputs and of outputs, and they continuously improved the production processes. Challenging for the management was that Merck's in-house R\&D capacities were scattered over different departments of the company. First of all, Willy Merck, co-owner of the firm and head of the production department, was an active researcher. Moreover, subordinate managers in the production department, in particular Carl Scriba, were often trained chemists with an interest in process optimization. Furthermore, chemists and pharmacists were employed in the control laboratory, the scientific information department, the bacteriological department, and - last but not least - the central research laboratory, which was established in $1898 .^{57}$ Furthermore, the research-related organisational units did not have well-defined areas of research, but intersected on many themes.

The control laboratory tested the quality of inputs delivered to Merck and of the outputs to be shipped to customers. In addition, it traced the origin of customers' complaints regarding product quality. During the business year 1897/ 98, for example, 9,638 preparations were evaluated in the control laboratory. At the time, two trained chemists, Dr. Braun and Dr. Neubert, between six and eight blue-collar workers, and one white collar worker were employed in the laboratory. ${ }^{58}$ Moreover, it was involved in process optimization, a task also fulfilled by the production units and the central scientific laboratory.

The scientific information department, established in 1888, was mainly responsible for the information of the public about the latest innovations and of available products in pharmacy. The information was circulated using 'Merck's Jahresberichte' (Merck's digest), a booklet published in several languages and distributed all over the World. ${ }^{59}$ The 1898 edition of Merck's digest was, for example, published in four languages (German, English, French, and Russian) and distributed in 27,000 copies to customers and scientists worldwide. The production of this report was the main task of Dr. Paul Zipperer, head of the scientific information department. Moreover, Zipperer, a clerk and a part-time chemist, were responsible for responding to scientific questions arising from the departments of the company, from customers, and from outside scientists. In

57 Therefore, Merck established a centralized research unit long before the foundation of its pharmaceutical research laboratory in 1927.

58 MRO F3/2a.

59 The following discussion is based on the review of activity of this department during the years 1888-1899, published in Merck’s internal report for the business year 1898/ 99. MRO F3/3a. 
1898, for example, 420 scientific correspondences with customers and outside researchers were handled and 2,175 enquiries from the various departments of the company were answered. Furthermore, the department organized the scientific library as well as the circulation of 56 scientific journals inside the company. Finally, members of the scientific information department supported the other laboratories and tested 48 drugs and made 40 experiments.

Bacteriological research was conducted at Merck since 1895 in the bacteriological production department headed by Dr. von Buisson. In addition, in August 1900 the bacteriological research laboratory headed by Dr. Landmann was established. Three years later, a new head of bacteriological research was hired: Wilhelm Eicholz, who earned his PhD in chemistry in 1901 from Emil Fischer. Eichholz was one of the longest-serving researchers at Merck and he stayed at the firm until his death in $1927 .{ }^{60}$ His most important contributions were his participation in the Jodipin research and his invention of a dysentery serum in $1906 .{ }^{61}$ The main tasks of the bacteriological research laboratory were the quality control of the products of the bacteriological production units as well as research regarding tubercle, typhus, and diphtheria. However, the resources for research were rather limited. For example, resources devoted to the development of the first bacteriological drug, Tuberculol, were just 23,216.37 Mark, spent over a period of eleven years. ${ }^{62}$ Furthermore, Dr. Landmann was part-time delegated to the bacteriological production department. Moreover, the research unit was involved in quality control. For instance, 105 samples of the production department were investigated in the bacteriological research laboratory during $1900 / 01{ }^{63}$ Nevertheless, in 1902, sera fighting tubercle, pneumococcus, and streptococcus were launched, followed by a diagnostic drug for typhus one year later. ${ }^{64}$ Later on, research regarding diphtheria, typhus, and streptococcus was in the focus of the laboratory's staff. ${ }^{65}$ Parallel to the bacteriological research conducted in Darmstadt, a bacteriological research unit was established in co-operation with Professor Sobernheim in Halle. Merck installed a research unit in Halle, directed by Sobernheim and staffed with Merck's own researcher, Dr. Burow. Burow started his research in May 1902 and worked for Merck until May $1911 .^{66}$ In particular, research in and production of an anthrax serum was conducted in Halle.

The central scientific laboratory, headed by the chemist Dr. Alexander Ehrenberg, was founded in 1898 by combining the departments for synthetic analysis, the analytical laboratory, the electro-chemical laboratory, the patent office, and the marketing department. ${ }^{67}$ Already one year later, the central research laboratory was re-organized by dividing it into four sub-units: (i) the

\footnotetext{
$60 \quad$ MRO F3/1b.

$61 \quad$ MRO J 10/715.

62 MRO F3/5a. Merck made these expenditures between 18 March 1890 and 30 June 1901. Expenditures for a lymphe serum and another tubercle serum were 7,589.37 Mark (1 June 1896-30 June 1901) and 3,468.55 Mark (24 May 1897-30 June 1901; Tuberculinum Kochii), respectively.

$63 \quad \mathrm{MRO}$ F3/5c.

64 MRO F3/7a and MRO F3/7a. From a commercial point of view, these drugs were unimportant. In 1912, the turnover generated by the five drugs was less than 75,000 Mark and they made a profit of about 9,000 Mark.

65 MRO F3/12c. In 1908, the bacteriological laboratory employed 18 blue-collar workers and one researcher, Dr. Eichholz.

66 MRO R 15/11. Contracts Merck with Burow, 25 April 1902 and 15 May 1911.

67 MRO F3/2c.
} 
operations laboratory; (ii) the experimental laboratory; (iii) the electro-chemical department; (iv) the office for patents and marketing. This organisational structure remained in place at least until World War I.

Dr. Holzinger, the first staff member of the operations laboratory, improved the blueprints for new products from a laboratory scale to an industrial scale. Moreover, many new products were first produced and sold by the operations laboratory. Production was handed over to the production department when the process was fully developed. The experimental laboratory, staffed first by Dr. Kassner and Dr. Schnerr, had three main tasks. First, it checked inventions offered to Merck by outside inventors regarding the applicability on an industrial scale; second, it improved established production processes; third, it developed new products. The electro-chemical laboratory, staffed with Dr. Pip from 1898 onwards, participated in the research projects of the operations and experimental laboratory by applying electro analysis. The office for patents and marketing, finally, was responsible for safeguarding Merck’s inventions, monitoring the patenting activities of competing firms, and circulating Merck's research results among scientists, users, and customers. In this office, Dr. Mennel was responsible for patents and Dr. Rahn for marketing. ${ }^{68}$

The size of Merck's central research laboratory remained quite similar over time: the average number of researchers was eight, with nearly no fluctuation in absolute numbers, but with significant fluctuation of individual researchers. More specifically, two career paths were common in Merck's central research laboratory. First, some researchers stayed in their positions for very long periods. Examples are Dr. Pip, head of the electro-chemical laboratory from 15 January 1898 and Dr. Beckh, who started on 1 December 1899 as a researcher in the experimental laboratory. Both stayed in research - at least - until World War I. Other examples are Dr. Knell and Dr. Wolfes, who joined the experimental laboratory to conduct research on the barbiturate Veronal on 1 April 1903 and 21 November 1904 respectively; both stayed at least until World War I. The second typical research path was the move from research into production. Examples are Dr. Gruschwitz and Dr. Weber, members of the experimental laboratory during 1903-07 and 1904-07 respectively. Other examples are Dr. Immel and Dr. Seuffert, who were members of the experimental laboratory for two years (1901-03), and Dr. Müller, who was a researcher for just six months in 1909.

Merck's central research laboratory main task was the ' $D$ ' part of $R \& D$, i.e., the optimization of production processes for large-scale production. This function can be quantified by counting the process innovations discussed in the annual reports of Merck's scientific laboratory: 88 percent of all process innovations can be ascribed to in-house researchers, whereas only six percent each originated from university researchers and free inventors.

The annual reports of the laboratory also include numerous case studies for process optimisation. For example, Albert Ladenburg, professor for chemistry in Breslau, demonstrated in 1894 the 
electro-chemical reduction of pyridine to piperidine. One of the first tasks of Dr. Pip, head of the electro-chemical research unit, was the adaptation of Ladenburg's method to an industrial scale. He succeeded soon and generated piperidine at a cost of 70 Mark per kg, 50 Mark per kg less than the original method. In addition, an optimized arrangement of the production process and the use of a modern filter press reduced the costs further to 50 Mark per kg. Merck's researcher proposed to the management of the firm that the knowledge about the new substance should be circulated in universities. Then, some technical or medical use of piperidines was expected to be found soon. ${ }^{69}$ Indeed, some time later, piperidine became an important intermediate in the synthesis of drugs.

Another example for process development relates to the research concerning the barbiturate Veronal, invented in 1903 by Fischer and von Mehring, who were outside researchers for Bayer and Merck, respectively. Consequently, this first barbiturate was produced by Bayer and Merck using very similar methods. Merck soon figured out that the theoretical derivation and small-scale laboratory production of this barbiturate were insufficient for industrial production. Consequently, Merck hired two new researchers, Dr. Klein and Dr. Knell, to work exclusively on Veronal. The first major problem was the immense demand for the new drug, making large-scale production inevitable. Before the launch of the new drug, Merck estimated an annual demand of $500 \mathrm{~kg}$. Yet, the production capacity had to be expanded to 5,000 kg per annum within the first year and a further increase to $10,000 \mathrm{~kg}$ seemed possible if the production unit was used 24 hour a day. ${ }^{70}$ During the following year, Veronal-related research capacities at Merck were increased further as Fischer's former research assistant Dr. Wolfes was hired by the company. He was worth his money, since he substantially improved the use of alcohol in the production process. Thereby, he increased the rate of yield from 38 percent to 60 percent. Moreover, it seemed possible to increase the rate of yield to 70 percent. Nevertheless, Dr. Beckh, another researcher at Merck, reverse engineered the method used by Bayer and figured out that Bayer's rate of yield was even higher. Nevertheless, Merck's method was less expensive at the actual input prices. ${ }^{71}$ Naturally, Veronal's high profitability - the profit-turnover ratio was 35 percent in 1903/ 04 attracted market entrants. For example, Schering and Hoechst earned money on a Veronal-like drug using a method that had just one-third of the rate of yield of the Bayer-Merck method. Yet, Merck protected its product by applying for a series of patents around the original Veronal patent. In June 1905, just two years after the launch of Veronal, Merck already held 65 patents regarding Veronal - about two-thirds of Merck's total patent stock was therefore related to this drug. ${ }^{72}$

69 MRO F3/2c. „Vor allem muß man jetzt versuchen, Universitäten und technische Hochschulen für das Piperidin zu interessieren, arbeiten größere wissenschaftliche Kreise mit diesem Stoffe, so wird sich auch bald eine Verwertung gefunden haben, sei es nun in medizinischer oder technischer Beziehung.“

$70 \quad$ MRO F3/7c.

71 MRO F3/8c.

72 MRO F3/9c. During 1905/ 06, the situation had stabilised and the prominence of Veronal in the research laboratory declined. Merck's method was nearly as efficient as the one used by Bayer. In addition, Hoechst's production was eliminated by a decision of the patent office. Schering's production was interrupted by a decision of the patent office. MRO F3/10c. 
The third example of process optimization concerns the production of tannins, an important raw material for the production of herbal pharmaceutics. ${ }^{73}$ During the mid-1890s, Merck's position in this market was endangered by a new process developed by Schering. To counter this attack, Merck experimented with five new processes for the production of tannins. The six input factors had to be composed in a way that the four different types of outputs were generated in a profitmaximizing way at given market prices. In a first step, a new method was theoretically developed. This new method reached a rate of yield of 72 percent, much better than the 64 percent of Merck's old method and above the rate of yield of Schering's method. In a second step, the theoretical results had to be applied in practice. Between January and April 1897, Merck's chemists tried five different modes of production. In practice, the new method had a rate of yield of 70.23 percent, less than the model predicted for Merck's method, but higher than the old process. As a result, the new process resulted in a decline of production costs from 2.60 Mark per kg to 2.20 Mark per kg of tannin. The fact that the decline in production costs was relatively higher than the increase of the rate of yield is striking. This indicates that Merck's researcher did not only improve the process, but that they also optimized the structure of input factors in view of current prices. Moreover, the researchers expected declining costs due to learning effects of the workers and due to a new design of the manufacturing facility, which was expected to reduce the loss of ether, an input factor. Consequently, the chemists projected a decline of production costs to 2.10 Mark per kg, nearly 20 percent less than the unit costs of the old process. ${ }^{74}$

In-house product development, on the other hand, mostly failed. A striking example is the production of vanillin and heliotropine, two basic materials for perfume production. In 1874, the first chemical production of vanillin using the sap of spruce bark was realized by the German chemists Wilhelm Haarmann and Ferdinand Tiemann, who founded a firm - Haarmann's Vanillin-Fabrik - to exploit the patent. However, it took more than a decade and the invention of vanillin production using eugenol in 1891, to make the chemical production of it a big commercial success. A few years later, Merck decided to enter this market. During the business year 1897/ 98, a new, four-step production method for vanillin was developed by Merck's researchers. The first step was the relocation of eugenol to iso-eugenol using a new method, which was not in conflict with existing patents. However, the new method was not revolutionary enough to get a patent. In the second step, the iso-eugenol was acetylated and the resulting product was - in step three - oxidated to acetvanillin. Finally, vanillin was separated from acetvanillin. Moreover, economies of scope could be realized since the same instruments and machines used for the production of vanillin could also be used in the production of heliotropine. ${ }^{75}$ One year later, Merck received a patent for step two of its new method. Furthermore, large-scale experiments were conducted to get data for the estimation of future production costs and to optimise the production process. In addition, two investment plans were presented to the management of the firm. An entirely new facility for the production of vanillin and heliotropine would cost about 40,000

73 The relevance of tannins for Merck can be shown using revenue and profit figures for 1908 and 1909. During these two years, tannins generated a turnover of more than 700,000 Mark (about 4 percent of total turnover) and profits of more than 110,000 Mark. MRO H5/9a. 
Mark, whereas the conversion of existing facilities would be possible at a cost of only 16,000 Mark. The latter plan was agreed upon and the production on an industrial scale was bound to start during $1900 .{ }^{76}$ However, it turned out that Merck's method had a much lower rate of yield than expected from the laboratory experiments. Simultaneously, the market price of vanillin declined substantially. Consequently, Merck was not able to compete on the product market. Nevertheless, the management decided to continue the production since substantial fixed costs had already been sunk. ${ }^{77}$ Yet, prices for vanillin and heliotropine declined further and the production was stopped in 1901, about one year after Merck's entry into the market. ${ }^{78}$

At regular intervals, shortages of resources devoted to $R \& D$ were discussed in the annual reports of the central research laboratory. For example, resources were temporarily shifted from the central research laboratory to the production units. ${ }^{79}$ Another example of resource constraints concerned the electro-chemical department. This department should have been equipped with many complex installations, but the necessary office and laboratory space was sometimes unavailable. ${ }^{80}$ A final example concerns the experimental laboratory. Due to missing office space in the laboratory, no new scientists were hired in 1902 after the promotion of Dr. Immel and Dr. Seuffert into the production department. ${ }^{81}$ Even one of the core activities of the central research laboratory, the protection of drugs using the patent system, was sometimes not completely fulfilled. The report for 1899/ 1900 states, for example, that the experiments to extend the patent protection of Merck's cocaine processes were of only secondary importance for the researchers. ${ }^{82}$ Furthermore, the use of patent lawyers was restricted as far as possible to save money, and the corresponding tasks were performed in-house by Merck’s patent department. ${ }^{83}$ Moreover, investment into laboratory equipment was sometimes delayed for several years, making some experiments impossible. ${ }^{84}$

The remuneration of in-house researchers was very moderate, in particular if compared to the compensation of outside inventors. Merck's standard working contract for chemists during the

76 MRO F3/3c. Moreover, it turned out that the same method could be employed to produce paracetamol, a Aspirin-like drug.

$77 \quad \mathrm{MRO} F 3 / 4 \mathrm{c}$.

78 MRO F3/5d.

79 In 1908, Dr. Silberbach was delegated in the production department. During the following year, several research chemists were delegated into the production department during the summer. During 1910 and 1911, a substantial part of the research manpower was delegated to the cocaine production. In 1913, research capacity was shifted to the control laboratory since the researcher there was snowed under with work.

80 MRO F3/3c for 1898/ 99, MRO F3/7c for 1902/ 03.

81 MRO F3/6c.

82 MRO F3/4c. Report of the head of the scientific laboratory, Dr. Ehrenberg, regarding cocaine research: „,...] Bei dieser Gelegenheit will ich indessen darauf aufmerksam machen, daß derartige Arbeiten im wissenschaftlichen Laboratorium durchaus nicht als Hauptsache angesehen werden, sondern daß sie zur Ausfüllung der bei den großen laufenden Hauptaufgaben übrig bleibenden Zeit dienen.“

83 MRO F3/4c.

84 The 1908 report stated that the operations laboratory received, after several years of waiting, a large centrifugal and a large agitating tub. The head of the scientific research laboratory, Dr. Beckh, claimed that this delay had negative consequence, for the scientific work as well as for the whole company: "Es kann nicht scharf genug auf den Schaden hingewiesen werden, welcher nicht nur der Wissenschaft, sondern auch der Fabrik durch ein derartiges Gebahren entsteht, und es ist zu hoffen, daß die jetzt vorhandenen Anfänge einer Versuchsapparatur für Fabrikationszwecke dem Laboratorium dauernd erhalten bleiben.“ 
early $20^{\text {th }}$ century prescribed that chemists were initially hired for one year, followed by an openended contract with a period of notice of three months. The annual fixed income varied between 2,400 Mark and 4,500 Mark. All inventions made were automatically transferred to Merck, and most contracts did not contain a profit-sharing agreement. ${ }^{85}$ In this respect, Merck differed from Bayer, where the researchers received a share in product specific profits of up to five percent (Wimmer, 1994: 124-126; Meyer-Thurow, 1982: 373-375). Yet, in-house researchers at Bayer only received this profit share for new products and not for process improvements of external inventions. Therefore, Bayer's in-house research staff impeded the acquisition of externally developed products (Wimmer, 1994: 140-141). In this respect, Bayer substantially differed from Merck and Hoechst.

The intensity of the Veronal research and the resource constraints after 1908 were, in a way, responsible for the decline of in-house research at Merck. On the one hand, Veronal induced a rise of research capacities, since new scientists were hired. On the other hand, nearly all researchers were engaged in Veronal-related research between 1903 and 1906. As a result, the number of new patents declined tremendously after the end of the Veronal wave. Moreover, researchers were regularly delegated into the production department. Consequently, the research output declined substantially. Jointly and severally, nearly no new research results were published in the reports of the central research laboratory after 1908. In 1909, Dr. Beckh summarised the situation for in-house research at Merck: ${ }^{86}$

“Although factory management has, over the years, not changed its mind as regards the many concerns facing the introduction of new drugs - concerns I myself share to a large degree -, nonetheless I cannot avoid being convinced that experiments aimed at obtaining new synthetic drugs should not be allowed to disappear altogether from the agenda of a scientific laboratory. This kind of work, particularly when it comes to inventing such superior quality products as Veronal, can be compared to a veritable hunt for the jackpot. And even if one contents oneself with a lesser level of success, if one goes only for the minor successes, this means a huge amount of futile work. mund Carl Burchard (1 July 1911, 4,500 Mark fix, unspecified profit share for inventions); Dr. A. Pister (10 August 1914, 3,960 Mark fix); Dr. Ludwig Wolter (1 December 1914; 2,400 Mark fix).

86 "Wenngleich sich die Anschauung der Fabrikleitung über die vielerlei Bedenken, welche der Einführung neuer Arzneimittel entgegenstehen, im Lauf der letzten Jahre nicht geändert hat, Bedenken welche ich selbst in hohen Maße teile, so kann ich mich doch der Überzeugung nicht verschließen, daß Versuche zur Gewinnung neuer synthetischer Arzneimittel nicht vollständig aus dem Arbeitsprogramm des wissenschaftlichen Laboratoriums ausgeschaltet werden dürfen. Die letztere Art von Arbeiten läßt sich, zumal wenn man Körper von so souveräner Qualität, wie das Veronal suchen will, wohl mit Jagen nach dem großen Loos vergleichen. Und selbst wenn man mit minderen Erfolgen zufrieden sein will, wenn man nur die kleineren Treffer sucht, steckt eine endlose Menge vergeblicher Arbeit darin. [...] Durch Vervollkommnung unserer Betriebsmethoden werden wir unsere bisherigen großen Fabrikate wohl in der Mehrzahl der Fälle auf der Höhe halten können und unsere Absatzgebiete behaupten, einen direkten FORTSCHRITT bedeutet dies aber nicht. Dabei müssen wir immer noch gegenwärtigen, daß die wirkliche chemische Großindustrie, die Farben- und Säurefabriken infolge der intensiv gesteigerten Konkurrenz sich allmählich unseren größeren Präparaten zuwenden, sie werden dann zweifellos in der Lage sein, selbst bei gleichwertigen Fabrikationsmethoden uns infolge der billigeren Rohstoffe in den betr. Artikeln zu unterbieten und so den Konsum an sich zu ziehen. Es sollte daher zur rechten Zeit Nachwuchs geschaffen werden, aber nicht durch aussichtslosen Kleinkram sondern durch einige gute Spezialitäten, dann durch Aufnahme einiger neuer Fabrikationszweige, die durch die Größe des Absatzgebietes und durch den Nutzen, mit dem sie nachweislich von anderer Seite vertrieben werden, eine Garantie für dauerhafte Rentabilität bilden.“ MRO F3 / 13d. 
[...] By perfecting our operational methods we will most probably be able to maintain most of our major products on the same high standard, as well as holding our key markets; yet, this does not inevitably mean PROGRESS. We must still bear in mind that the real large-scale chemical industry, the dyestuff and acid factories, are gradually looking into producing the very same key substances we make, as a result of consistently growing competition. Using the same production methods as we do, they will no doubt soon be able to underbid us in these products, due to cheaper raw materials, thus attracting the consumer. For this reason, the ground should be prepared for new innovations as soon as the time is right - not just some unpromising odds and ends, but a few good specialist products. Then, other new branches should be taken on board. This would provide a guarantee for sustainable cost-effectiveness as a result of an increased market area and demonstrable usefulness.”

Moreover, Dr. Beckh asked for better co-operation between chemists and medical scientists, as well as for intensified co-operation with university researchers. In particular, the scientific information department should improve the flow of information from practioners and university researchers to the members of the central research laboratory. Only when these pre-conditions are met, the central research laboratory could focus on the most important research topics. ${ }^{87}$

\section{Conclusion}

During the 1880s and 1890s, traditional, alkaloid-based pharmaceutical research was challenged by the bacteriological revolution and by the discovery of dyestuff-based drugs. In addition, the latter development caused the market entry of dyestuff producers on the market for pharmaceuticals. Consequently, product market competition intensified substantially at the turn of the $20^{\text {th }}$ century. Moreover, some dyestuff producers - especially Bayer - started systematic research to discover new drugs. Thereby, the traditional trial-and-error approach of alkaloid-based pharmaceutical research used by incumbent producers like Merck came under pressure. Furthermore, the foundation of the state-sponsored health insurance in Germany during the 1880s and the modification of the German patent law in 1891 increased the demand for drugs and enhanced the possibilities to appropriate profits from patent-protected products. Finally - and exceptionally for the family-owned firm Merck - a new generation of family members took over the management of the firm during the 1880s and 1890s. Jointly and severally, the period between 1890 and 1913 was challenging for Merck.

Merck responded to these multiple challenges by adapting its research strategy and organisation. First, a significant number of long-term research co-operations were initiated during the 1890s. In this regard, Merck's strategy was similar to the one used by Hoechst, one of the large dyestuff producers entering the market for pharmaceuticals during the 1880s. Nearly all products launched by these firms were developed by university researchers, who were connected to the firms via long-term contracts. During the early 1890s, Bayer followed a similar strategy. Yet, at the turn of the century its in-house research capacities were sufficient to develop a continuous flow of new products. Schering, like Merck a traditional pharmaceutical company, was, on the 
other hand, neither successful in establishing external research co-operations nor in setting-up inhouse research capacities. ${ }^{88}$

Second, Merck addressed the bacteriological revolution by setting-up a bacteriological production unit in 1895. A bacteriological research laboratory was established in 1900. Finally, a close and long-lasting research co-operation with Professor Georg Sobernheim from the University of Halle began in 1902. In bacteriological research, Merck was not outpaced by its major competitors. More specifically, Hoechst established in-house bacteriological research only in 1903, after the breakdown of the path-breaking research co-operation with Emil von Behring. Nevertheless, Hoechst kept its leading position in the market for bacteriological drugs. Bayer, on the other hand, did not focus on bacteriological research, and most of its drugs were based on salicylic acid derivatives. Schering, finally, established a bacteriological unit as early as 1893. However, the research activities of the firm mostly failed. By and large, Merck did not become a major player in bacteriological drugs. Nevertheless, the firm profitably produced the full range of those drugs during the pre-World War period.

Third, Merck strengthened its in-house research capacities in 1898, the foundation year of its central research laboratory. Merck's laboratory was, however, smaller than the research units of Bayer or Hoechst. In addition, the resources devoted by Merck to in-house research were often insufficient. Nevertheless, Merck successfully screened new products offered to the firm by outside inventors. Moreover, the firm established sufficient skills in chemical engineering to upgrade the production processes of bought drugs from laboratory conditions to industrial scale. Merck's in-house research strategy was therefore comparable to Hoechst's. Yet, the flow of outside inventions flattened during the years preceding the Great War. On the other hand, resources devoted to in-house research were insufficient to compensate this development. In this respect, Merck's development mirrors Hoechst's experience during the same period. A possible strategic shift was perhaps delayed by the Great War: Hoechst founded its central pharmaceutical research laboratory in 1913, whereas Merck established its pharmaceutical research laboratory in 1927, after the Great War and the period of hyperinflation.

88 The close co-operation between industry and university was also common in the U.S. Furman / MacGarvie (2007) have shown that close industry-university co-operation caused a flow of knowledge from universities to firms during the inter-war period. 


\section{References}

\section{Archival sources from Merck Record Office (MRO)}

F 1 / 47 Merck-Knoll / Stypticin-Stypta / Prof. Freund, 1906/ 07

F 3 / 1a Jahresbericht für das Betriebsjahr 1. Juli 1896 bis 30. Juni 1897

F 3 / 1b Jahresbericht für das Betriebsjahr 1. Juli 1896 bis 30. Juni 1897

F 3 / 2a Jahresbericht für das Betriebsjahr 1. Juli 1897 bis 30. Juni 1898

F 3 / 2c Jahresbericht für das Betriebsjahr 1. Juli 1897 bis 30. Juni 1898

F 3 / 3a Jahresbericht für das Betriebsjahr 1. Juli 1898 bis 30. Juni 1899

F 3 / 3c Jahresbericht für das Betriebsjahr 1. Juli 1898 bis 30. Juni 1899

F 3 / 4a Jahresbericht für das Betriebsjahr 1. Juli 1899 bis 30. Juni 1900

F 3 / 4c Jahresbericht für das Betriebsjahr 1. Juli 1899 bis 30. Juni 1900

F 3 / 5a Jahresbericht für das Betriebsjahr 1. Juli 1900 bis 30. Juni 1901

F 3 / 5c Jahresbericht für das Betriebsjahr 1. Juli 1900 bis 30. Juni 1901

F 3 / 5d Jahresbericht für das Betriebsjahr 1. Juli 1900 bis 30. Juni 1901

F 3 / 6c Jahresbericht für das Betriebsjahr 1. Juli 1901 bis 30. Juni 1902

F 3 / 7a Jahresbericht für das Betriebsjahr 1. Juli 1902 bis 30. Juni 1903

F 3 / 7c Jahresbericht für das Betriebsjahr 1. Juli 1902 bis 30. Juni 1903

F 3 / 8a Jahresbericht für das Betriebsjahr 1. Juli 1903 bis 30. Juni 1904

F 3 / 8c Jahresbericht für das Betriebsjahr 1. Juli 1903 bis 30. Juni 1904

F 3 / 9a Jahresbericht für das Betriebsjahr 1. Juli 1904 bis 30. Juni 1905

F 3 / 9c Jahresbericht für das Betriebsjahr 1. Juli 1904 bis 30. Juni 1905

F 3 / 10c Jahresbericht für das Betriebsjahr 1. Juli 1905 bis 31. Dezember 1906

F 3/12c Jahresbericht für das Betriebsjahr 1. Januar 1908 bis 31. Dezember 1908

F 3 / 13d Jahresbericht für das Betriebsjahr 1. Januar 1909 bis 31. Dezember 1909

F 3 / 16a Jahresbericht für das Betriebsjahr 1. Januar 1912 bis 31. Dezember 1912

F 3 / 16d Jahresbericht für das Betriebsjahr 1. Januar 1912 bis 31. Dezember 1912

F 3 / 18a Jahresbericht für das Betriebsjahr 1. Januar 1914 bis 31. Dezember 1914

H 5 / 9a IG Korrespondenz 1907-1909

H 5 / 15 IG Korrespondenz 1906-1908

H 5 / 43 IG: Verträge und Korrespondenz

J 10 / 715 Gewinnbeteiligung Dr. Eichholz

R 1 / 42 Anstellungsverträge und Erfinderverträge

R 5 / 23 Verträge Prof. Dr. Martin Freund

R 15 / 11 Verträge mit Erfindern und Gelehrten A-K

R 15 / 12 Verträge mit Erfindern und Gelehrten L-Z

S 6 / 21 Merck’s Patent- und Specialpräperate, Zusammenstellung der Abrechnungen, Nr. 1-39

S 6 / 22 Merck’s Patent- und Specialpräperate, Zusammenstellung der Abrechnungen, Nr. 40-78 


\section{Printed sources and secondary literature}

Beer, J.J. (1959)

The emergence of the German dye industry

University of Illinois Press, Urbana

Bernschneider-Reiff, S. (2002)

„Was der Mensch thun kann...“: Die Geschichte von Merck - das älteste pharmazeutische Unternehmen der Welt

Merck, Darmstadt

Burkert, K. (1990)

Die deutsche „Pharmazeutische Interessengemeinschaft“ (1906-1908): Ein Beitrag zur Firmenpolitik der pharmazeutisch-chemischen Industrie bis zum Ende des Ersten Weltkrieges

Deutscher Apotheker Verlag, Stuttgart

Cameron, R. / Neal, L. (2003)

A concise economic history of the World

$4^{\text {th }}$ Edition, Oxford University Press, Oxford

Chandler, A.D. (2005)

Shaping the industrial century: The remarkable story of the evolution of the modern chemical and pharmaceutical industries

Harvard University Press, Cambridge / Mass.

Dominguez-Lacasa, I. (2006)

Capturing the changes in the knowledge base underlying drug discovery and development in the 20th century and the adjustment of Bayer, Hoechst, Schering AG and E. Merck to the advent of modern biotechnology

Scientometrics, 66, 2006, 345-364

Erker, P. (1990)

Zur Geschichte der Industrieforschung in den europäischen und amerikanischen Elektrokonzernen, 1890-1930

Zeitschrift für Unternehmensgeschichte, 35, 1990, 73-94

Furman, J.L. / MacGarvie, M.J. (2007)

Academic science and the birth of industrial research laboratories in the U.S. pharmaceutical industry

Journal of Economic Behavior and Organization, 63, 2007, 756-776 
Galambos, L. / Sewell, J.E. (1995)

Networks of innovation: Vaccine development at Merck, Sharp \& Dohme, and Mulford, 1895-1995

Cambridge University Press, Cambridge

Galambos, L. / Sturchio, J.L. (1998)

Pharmaceutical firms and the transition to biotechnology: A study in strategic innovation

Business History Review, 72, 1998, 250-278

Griliches, Z. (1990)

Patent statistics as economic indicators: A survey

Journal of Economic Literature, 28, 1990, 1661-1707

Grupp, H. / Dominguez-Lacasa, I. / Friedrich-Nishio, M. (2002)

Das deutsche Innovationssystem seit der Reichsgründung

Physica-Verlag, Heidelberg

Homburg, E. (1992)

The emergence of research laboratories in the dyestuff industry, 1870-1900

British Journal for the History of Science, 25, 1992, 91-111

Huhle-Kreutzer, G. (1989)

Die Entwicklung arzneilicher Produktionsstätten aus Apothekenlaboratorien

Deutscher Apotheker Verlag, Stuttgart

Kaiserliches Patentamt (various years)

Verzeichnis der im Jahre ... ertheilten und noch in Kraft befindlichen Patente

Carl Heymann, Berlin

Kobrak, C. (2002)

National cultures and international competition: The experience of Schering AG, 1851-1950

Cambridge University Press, Cambridge

König, W. (1995)

Technikwissenschaften: Die Entstehung der Elektrotechnik aus Industrie und Wissenschaft zwischen 1880 und 1914

Fakultas Verlag, Chur

König, W. (1996)

Science-based industry or industry-based science? Electrical engineering in Germany before World War I

Technology and Culture, 37, 1996, 70-101 
Landes, D.S. (1999)

The wealth and poverty of nations

W.W. Norton \& Co., New York

Lee, J. (2003)

Innovation and strategic divergence: An empirical study of the U.S. pharmaceutical industry from 1920 to 1960

Management Science, 49, 2003, 143-159

Liebenau, J. (1984)

Industrial R\&D in pharmaceutical firms in the early twentieth century

Business History, 26, 1984, 229-246

Liebenau, J. (1985)

Innovation in pharmaceuticals: Industrial R\&D in the early twentieth century

Research Policy, 14, 1985, 179-185

Löw, C. (1952)

Die chemische Fabrik E. Merck, Darmstadt: Ein Rückblick auf die Geschichte der Firma in Wort und Bild

E. Merck, Darmstadt

Metz, R. / Wattleder, O. (2002)

Historische Innovationsindikatoren: Ergebnisse einer Pilotstudie

Historical Social Research, 27, 2002, 4-129

Meyer-Thurow, G. (1982)

The industrialization of invention: A case study from the German chemical industry

ISIS, 73, 1982, 363-381

Murmann, J.P. (2006)

Knowledge and competitive advantage

Cambridge University Press, Cambridge

Reinhardt, C. (1995)

Vom Alizarinblau zum Thallin. Pharmezeutisch-chemische Forschung der BASF in den achtziger Jahren des 19. Jahrhunderts

In: Schütt, H.-W. / Weiss, B. (Ed.), Brückenschläge: 25 Jahre Lehrstuhl für Geschichte der exakten Wissenschaften und der Technik an der Technischen Universität Berlin, 1969-1994 Verlag für Wissenschafts- und Regionalgeschichte Engel, Berlin

Reinhardt, C. (1997)

Forschung in der chemischen Industrie: Die Entwicklung synthetischer Farbstoffe bei BASF und Hoechst

Unpublished PhD-Thesis, Bergakademie Freiberg 
Reinhardt, C. (1998)

An instrument of corporate strategy: The central research laboratory at BASF, 1868-1890 In: Homburg, E. et al. (Ed.), The chemical industry: Industrial growth, pollution, and professionalization, Kluwer Academic Publishers, Dordrecht, 1998, 239-259

Seckelmann, M. (2006)

Industrialisierung, Internationalisierung und Patentrecht im Deutschen Reich, 1871-1914 Vittorio Klostermann, Frankfurt am Main

Ungewitter, C. (1931)

Die großen Chemie-Konzerne Deutschlands

R. \& H. Hoppenstedt, Berlin

Wetzel, W. (1991)

Naturwissenschaften und chemische Industrie in Deutschland: Voraussetzungen und Mechanismen ihres Aufstiegs im 19. Jahrhundert

Franz Steiner, Stuttgart

Wimmer, W. (1991)

Tradition und Transformation: Die pharmazeutische Industrie in einem ständisch geprägten Markt

Zeitschrift für Unternehmensgeschichte, 36, 1991, 179-203

Wimmer, W. (1994)

„Wir haben immer was Neues“: Gesundheitswesen und Innovationen in der Pharma-

Industrie in Deutschland, 1880-1935

Duncker \& Humblot, Berlin

Wimmer, W. (1998)

Innovation in the German pharmaceutical industry, 1880 to 1920

In: Homburg, E. et al. (Ed.), The chemical industry: Industrial growth, pollution, and professionalization, Kluwer Academic Publishers, Dordrecht, 1998, 281-291 